\title{
HUBUNGAN ANTARA PERSEPSI SISWA TERHADAP KEPRIBADIAN GURU DAN JENIS KELAMIN SISWA DENGAN MINAT BELAJAR MATEMATIKA (Survei studi kasus terhadap siswa/i SMA Tugu Ibu Depok)
}

\author{
UL'FAH HERNAENY \\ Ulfah190409@yahoo.com \\ Program Studi Pendidikan Matematika, Fakultas Teknik, Matematika, Ilmu Pengetahuan Alam \\ Universitas Indraprasta PGRI (UNINDRA) \\ Tanjung Barat Jagakarsa, Jakarta Selatan
}

\begin{abstract}
Abstrac. Mathematics has an influence and a very large role in discovering and developing Science and Technology. For that, mathematics has priority in education. Student success in learning mathematics can be known from the ability to put that understanding to solve any mathematical problem and other problems in everyday life. Capabilities acquired by students in understanding the lessons in school because no other role of a teacher who is able to provide concepts is easily accepted by students. Personality of a teacher is affecting students' interest in studying mathematics. This study departed from the idea that the perception of students towards mathematics teacher's personality is affecting student interest in learning mathematics, students both male and female students. The purpose of this study, among others, want to know and analyze the relationship between student perceptions of teacher's personality and gender of students with interest in learning math in high school Yaspen Tugu Ibu Depok. As the population in this research determines the entire class $X$ school year 2005/2006, which consists of three classes with 120 people the number of students per class is 40 people. While the sample used is a class X A. Peneltian methods used to analyze the relationship between student perceptions of teacher's personality and gender of students with interest in learning math in high school Yaspen Tugu Ibu Depok method is to use descriptive correlative. The tendency of writers to use it because the method is explained and described the existing conditions of objects as well as coordinating existing objects. After the authors analyze the relationship between student perceptions of teacher's personality and gender of students to the interest in learning mathematics in high school Yaspen Tugu Ibu Depok, ultimately the author can draw the conclusion that there is a very significant and strong between teacher personality and gender of students with interest in learning mathematics.
\end{abstract}

Keywords: Perceptions of students, the teacher's personality, gender and interests of students studying mathematics.

\section{PENDAHULUAN}

Pendidikan merupakan hal yang sangat penting, Suatu Negara dapat di katakan maju apabila Negara tersebut mempunyai Teknologi yang baik dan maju, sedangkan kemajuan tidak lepas dari keberhasilan pendidikan.

Indonesia yang masih dalam kategori Negara berkembang, harus mampu mengejar ketinggalannya agar menjadi Negara yang maju, dengan cara memperbaiki dan 
menyempurnakan system pendidikan yang sudah ada. Upaya pembinaan dan pengembangan tersebut diarahkan pada pencapaian tujuan pendidikan nasional sebagaimana dirumuskan dalam Undang-undang Republik Indonesia No. 20 tahun 1989 tentang Sistem Pendidikan Nasional RI dan Peraturan Pelaksanaannya (Jakarta : Sinar Grafik 1992) cetakan ke-3 hal 4, yang berbunyi sebagai berikut :

"Pendidikan Nasional bertujuan untuk mencerdaskan kehidupan bangsa dan mengembangkan manusia Indonesia seutuhnya, yaitu manusia yang beriman dan bertakwa terhadap Tuhan Yang Maha Esa dan berbudi pekerti luhur memiliki pengetahuan dan keterampilan, kesehatan jasmani dan rohani, kepribadian yang mantap dan mandiri serta rasa tanggung jawab kemasyarakatan dan kebnagsaan".

Dari rumusan tersebut di atas jelas bahwa terbinanya manusia Indonesia yang berkualitas, beriman dan bertakwa terhadap Tuhan Yang Maha Esa serta berbudi luhur dengan memperhatikan aspek-aspek moral, kecerdasan dan keterampilan merupakan sasaran utama yang ingin dicapai oleh pendidikan. Sejalan dengan itu dikembangkan iklim belajar mengajar yang dapat menumbuhkan rasa percaya diri sendiri serta sikap dan prilaku yang inovatif dan kreatif. Dengan demikian Pendidikan Nasional akan mampu mewujudkan dirinya sendiri bersama-sama bertanggung jawab terhadap pembangunan bangsa.

Matematika merupakan satu dari unsur utama dalam membangun dan mewujudkan Ilmu Pengetahuan dan Teknologi, namun dalam kenyataannya banyak siswa SD, SMP, SMA maupun sederajat SMK memandang bahwa matematika sebagai mata pelajaran yang sukar dipahami dan tidak disukai.

Pelajaran matematika mempunyai pengaruh dan peranan yang sangat besar dalam menemukan dan mengembangkan Ilmu Pengetahuan dan Teknologi. Untuk itu matematika lebih diprioritaskan dalam pendidikan dan untuk mengukur sejauh mana keberhasilan dalam mempelajari matematika, dapat dijadikan tolak ukur untuk mengetahui tingkat penguasaan siswa terhadap konsep matematika. Untuk mengukur kemampuan siswa dalam memecahkan persoalan matematika yaitu dengann menggunakan tes. Keberhasilan siswa dalam mempelajari matematika dapat diketahui dari kemampuannya dalam menempatkan pemahaman tersebut untuk memecahkan setiap persoalan matematika maupun persoalan lain dalam kehidupan sehari-hari.

Dalam mencapai tujuan yang berpijak kepada dasar yang telah ditentukan dalam kurikulum Sekolah Menengah Atas, maka sangatlah diperlukan persyaratan kepribadian guru yang akan melaksanakan kurikulum itu. Betapa pun baiknya kurikulum dan cukupnya buku serta alat pelajaran namun tujuan kurikulum tersebut tidak memahami dan menghayati serta tidak berusaha mencapainya dengan keseluruhan pribadi dan tenaga yang ada padanya maka hasilnya akan sia-sia.

Guru bidang studi matematika yang mengajar pada sekolah tingkat lanjutan mempunyai tantangan yang lebih berat dibanding dengan tingkat sekolah dasar. Hal ini disebabkan karena masa remaja yang dilalui oleh siswa yaitu antara umur 16 sampai 19 tahun dapat dikatakan sebagai masa puncak kegoncangan jiwa. Pentingnya memiliki kepribadian yang menarik dapat dilihat dari peranannya dalam menumbuhkan respon positif dihati peserta didik terhadap guru mereka. Lebih dari itu, ia dapat menumbuhkan minat terhadap pelajaran yang diajarkan oleh guru yang bersangkutan, dalam hal ini pelajaran matematika, hingga pada akhirnya nanti akan menunjang keberhasilan proses mengajar yang dilakukan.

Dengan mengetahui akan keadaan jiwa siswa pada umur sekolah lanjutan tingkat atas, maka kepribadian guru akan sangat menentukan berhasil tidaknya sekolah itu mencapai tujuan yang telah digariskan. Adalah tidak bijaksana, apabila pihak sekolah mengabaikan persyaratan kepribadian bagi semua guru, sangat besar sekali pengaruhnya 
antara kepribadian guru terhadap minat belajar siswa dalam mengajar bidang studi yang diajarkan guru tersebut.

Permasalahan yang muncul adalah bagaimana kita dapat memahami mengenai siswa, baik itu siswa laki-laki maupun siswa perempuan, karakteristik yang dimiliki sehingga kita tahu bagaimana cara mempengaruhinya. Banyak siswa yang menilai baik positif maupun negative terhadap kepribadian guru dalam mengajar bidang studi yang diajarkan kepada siswa, baik siswa laki-laki maupun siswa perempuan mempunyai persepsi yang berbeda-beda terhadap kepribadian guru yang mengajar dikelas mereka terutama dalam bidang studi matematika. Persepsi yang berbeda inilah yang membuat peneliti ingin meneliti berapa besar persepsi siswa laki-laki maupun perempuan dalam menilai kepribadian guru matematika mereka baik itu kepribadian positif maupun negatif yang dihubungkan dengan minat belajar mereka terhadap matematika.

Minat yang tinggi terhadap suatu mata pelajaran memungkinkan siswa untuk memberikan perhatian yang tinggi terhadap mata pelajaran itu, sehingga memungkinkan pula memperoleh hasil belajar yang tinggi. Sebagai akibat dari keterkaitan siswa terhadap suatu mata pelajaran.

Dari uraian diatas terlihat bahwa persepsi siswa terhadap kepribadian guru memberikan pengaruh dengan minat belajar siswa dalam pelajaran matematika, sehingga diharapkan dapat mengatasi masalah prestasi belajar yang masih rendah khususnya hasil belajar matematika.

Berdasarkan permasalahan yang terungkap dalam paparan di atas maka masalah yang diteliti dalam penelitian ini dirumuskan sebagai berikut: (1) Adakah hubungan yang signifikan antara persepsi siswa terhadap kepribadian guru dan jenis kelamin siswa dengan minat belajar matematika di SMA Yaspen Tugu Ibu Depok? (2) Adakah hubungan antara jenis kelamin siswa dengan minat belajar matematika? (3) Adakah hubungan antara persepsi siswa terhadap kepribadian guru dan jenis kelamin siswa dengan minat belajar matematika?

\section{TINJAUAN PUSTAKA}

\section{Minat Belajar Matematika}

Banyak ahli-ahli pendidikan dan pengajaran yang mencoba memberikan definisi atau batasan-batasan dengan uraian yang berbeda-beda, namun pada umumnya mempunyai pengertian yang sama.

James O. Whittaker (2002: 132) menyatakan bahwa "Belajar sebagai proses dimana tingkah laku ditimbulkan atau diubah melalui latihan atau pengalaman".

Dalam Kamus Besar Bahasa Indonesia (2003: 729) menyebutkan " belajar adalah berusaha memperoleh kepandaian atau ilmu tertentu dengan tergantung pada kekuatan harapan bahwa tindakan tersebut akan diikuti oleh suatu hasil tertentu dan pada daya tarik hasil itu bagi orang bersangkutan".

Sementara itu, Slameto (2003: 2) menyatakan bahwa belajar adalah suatu proses usaha yang dilakukan individu untuk memperoleh suatu perubahan tingkah laku yang baru secara keseluruhan, sebagai hasil pengalaman individu itu sendiri dalam interaksinya dengan lingkungan.

Lisnawaty Simanjuntak (1998: 38) juga memiliki pendapat bahwa belajar adalah perubahan yang relatif menetap dalam potensi tingkah laku yang terjadi sebagai akibat dari latihan dengan penguatan yang tidak termasuk perubahan-perubahan karena kematangan, kelelahan, dan kerasukan pada susunan syaraf atau dengan kata lain mengetahui dan memahami sesuatu sehingga terjadi perubahan dalam diri seseorang yang belajar. 
Belajar itu sendiri adalah suatu proses perubahan dalam tingkah laku, dimana perubahan itu dapat mengarah kepada tingkah laku yang lebih baik.

Dari teori diatas, menyimpulkan bahwa belajar adalah proses perubahan di dalam kepribadian dan tingkah laku manusia dalam bentuk kebiasaan, pengetahuan, dan sikap berdasarkan latihan dan pengalaman untuk mengumpulkan pengetahuanpengetahuan melalui pemahaman, penguasaan, ingatan dan pengungkapan kembali diwaktu yang akan datang. Dalam belajar bukan hanya mengingat tetapi juga mengalami dan berinteraksi dengan lingkungan sekitar.

Minat belajar memegang peranan penting dalam proses belajar mengajar. Dengan adanya minat belajar akan membawa dampak senangnya mempelajari sehingga proses pencapaian belajar semakin baik. Menurut Guru Besar Psikologi dan Pengamat Pendidikan UNDIP "Minat belajar adalah kesenangan, kesukaan terhadap sesuatu sehingga adanya keinginan untuk mengetahui dan mengenal". Minat beljar menurut pendapat Crow dan Crow yang dikutip dari judul skripsi Evi Ruswanti sebagaimana yang dikutip oleh Abdurrahman Abrar mengemukakan bahwa:

"Minat bisa berhubungan dengan gaya gerak yang mendorong kita cenderung atau merasa tertarik pada seorang, benda atau kegiatan apapun bias berupa pengalaman yang efektif yang durangsang oleh kegiatan itu sendiri”.

Selanjutnya Bimo Walgito menyatakan bahwa "Minat adalah suatu keadaan dimana seseorang mempunyai perhatian sesuatu dan disertai dengan keinginan untuk mengetahui dan mempelajari maupun membuktikan lebih lanjut" (Bimo Walgito, 1999:45)

Jadi, suatu minat belajar dapat diekspresikan melalui suatu pernyataan yang menunjukkan bahwa seseorang lebih menyukai suatu hal dari pada hal yang lainnya, dapat pula dimanifestasikan melalui partisipasi dalam suatu aktifitas.

Siswa yang memiliki minat terhadap subjek tertentu cenderung untuk memberikan perhatian yang lebih besar terhadap subjek tersebut. Minat tidak tumbuh karena adanya paksaan tetapi karena adanya kesadaran dirinya, seperti minatnya terhadap pelajaran matematika akan membawanya terlibat aktif dalam pelajaran tersebut.

Dapat disimpulkan bahwa minat belajar adalah kegemaran atau kesukaan yang ada dalam diri manusia yang menghasilkan suatu hal yang lebih baik sehingga orang tersebut akan menekuni apa yang menjadi kesukaannya itu.

R Soedjadi (1999:25) memaparkan pengertian matematika sebagai berikut:

1. Matematika adalah cabang ilmu pengetahuan eksak dan teorganisi secara sistematik

2. Matematika adalah pengetahuan tentang bilangan dan kalkulasi.

3. Matematika adalah adalah pengetahuan tentang penalaran logik dan berhubungan dengan bilangan.

4. Matematika adalah pengetahuan tentang fakta-fakta kuantitatif dan masalah tentang ruang dan bentuk.

5. Matematika adalah pengetahuan tentang struktur yang logis.

6. Matematika adalah pengetahuan tentang aturan yang ketat

Dalam Kamus besar bahasa Indonesia (2003:723) dikatakan bahwa matematika adalah ilmu tentang bilangan, hubungan antara bilangan, dan prosedur operasional yang digunakan dalam menyelesaikan masalah mengenai bilangan.

Menurut Herman Hudoyo (1990:4)bahwa tujuan belajar matematika adalah mencakup kemampuan pengetahuan, komprehensif, aplikasi,analisis,sintesis dan evaluasi.

Matematika adalah ilmu seni kreatif. Dalam disiplin matematika konsep-konsep yang mendasarinya diperoleh melalui penalaran dan kreatifitas sedangkan kebenaran 
akan konsep didasarkan atas kaidah ilmiah, pola ini membuat matematika dapat dipelajari oleh setiap individu yang membutuhkannya serta terbuka bagi perkembangan untuk konsep dan penemuan baru.

Metematika sebagai ilmu pengetahuan timbul karena pikiran-pikiran manusia yang berhubungan dengan ide, proses dan penalaran yang menitik beratkan pada struktur dan sistem matematika.

Oleh karena itu matematika memerlukan simbol-simbol untuk menciptakan suatu komuniksai dan berguna untuk memberikan keterangan dalam bentuk suatu konsep baru, dengan memahami terlebih dahulu konsep sebelumnya. Dengan simbol itulah menunjukkan keunggulan ilmu matematika dari ilmu lainnya, sehingga penyelesaian masalah yang berhubungan dengan matematika dapatdisederhanakan dan diselesaikan dengan cepat.

Berdasarkan teori-teori yang dikemukakan diatas maka dapat disimpulkan bahwa minat belajar matematika adalah kegemaran atau kesenangan terhadap pelajaran matematika yang akan membawanya terlibat aktif dalam pelajaran tersebut.

\section{Persepsi Siswa Terhadap Kepribadian Guru}

Guru adalah pendidik yang bertugas mendidik. Kata "mendidik" itu sendiri berarti memelihara dan memberi latihan (ajaran, pimpinan) mengenai akhlak dan kecerdasan pikiran. Dalam hal ini akhlak berarti budi pekerti atau kelakuan. Dengan demikian, pendidik terlibat dalam proses pengubahan sikap dan tata laku seseorang atau sekelompok orang dalam usaha mendewasakan manusia melalui upaya pengajaran dan pelatihan. Jadi, upaya mendewasakan manusia yang mencangkup akhlak (moral) dan kecerdasan pikiran tidak terus dilakukan didalam ruang kelas. Ini berarti bahwa seorang guru tetap bertanggung jawab menjalankan peranannya walaupun diluar jam mengajarnya. Dia berperan dalam pengembangan budi pekerti atau kelakuan anak didiknya bukan hanya sekedar bertumpu pada pengalihan informasi.

Untuk menjalankan peranannya sebagai pendidik dalam proses belajar mengajar, seorang guru perlu member contoh-contoh penerapan praktis kepada anak didik, menggunakan istilah-istilah yang sederhana tapi jelas, serta menanyakan soal-soal yang penting supaya apa yang dipelajari dapat lebih mudah dipahami. Disamping itu, guru juga perlu memberikan kesempatan kepada anak didiknya untuk mau mengungkapkan apa yang menjadi kebutuhan dan kesulitan mereka dalam belajar. Dari pengungkapan ini akan terlihat kesulitan mereka dalam belajar. Dari pengungkapan ini akan terlihat kesulitan mereka sehingga guru pun bias menyajikan bahan yang sesuai dengan kebutuhan anak didik. Selain itu, cara ini juga memungkinkan guru untuk dapat menolong anak didik yang mengalami kesulitan dalam belajar.

Menurut Lawrence O. Richards (Kompos, 2005:26) sebagai seorang tokoh pendidik mengemukakan bahwa yang mengahambat seorang pendidik adalah bila guru mengharapkan hasil pengajarannya secara otomatis dan "instan" (cepat/kilat) dapat diterima oleh anak didik tanpa memikirkan aspek dan tahap-tahap belajar. Oleh karena itu, beliau mengemukakan aspek-aspek dan tahap-tahap belajar yang dapat menolong pendidik untuk lebih mengenal anak didiknya. Adapun aspek dan tahapan belajar itu adalah sebagai berikut;

1. Tahap menghapal tanpa berfikir

2. Tahap mengenali

3. Tahap mengucapkan kembali dengan kata-kata sendiri

4. Tahap menghubungkan

5. Tahap merealisasi/mewujudkan 
A.Sadli memaparkan pengertian guru adalah sebagai berikut :

"Individu yang akan memenuhi kebutuhan anak didik dalam bidang pengetahuan, melalui proses interaksi dalam rangka penyampaian dan penerimaan pendidikan, baik yang bersifat kognitif maupun psikomotor" (A.Sadli, 2005:56)

Dari uraian diatas dapat disimpulkan bahwa guru adalah seorang pendidik atau pembimbing yang tugasnya untuk mendidik dan mengarahkan kegiatan belajar siswa maupun sebagai pengajar dalam proses mengajar.

Guru adalah seorang pendidik yang mempunyai tugas dan tanggung jawab yang tidak kecil, oleh karena itu dalam keseluruhan proses pendidikan, diharapkan guru dapat mendorong siswa untuk belajar secara aktif dan dapat meningkatkan kemampuan pemecahan masalah yang menjadi jantungnya dalam matematika.

Menurut kamus besar Bahasa Indonesia 'Persepsi adalah pikiran atau anggapan bahwa sesuatu itu benar dilihat dari panca indera". Adapun sumber dari Buletin Romantika PGP-Maret (1983) "Persepsi adalah pandangan terhadap suatu objek yang dilihat baik secara langsung maupun tidak langsung".

Setiap manusia mempunyai pikiran yang berbeda-beda terhadap suatu hal, tergantung kesan pertama yang dilihat. Persepsi lebih dekat dengan pendapat atau pandangan seseorang terhadap suatu objek, objek disini adalah seorang guru matematika. ketika guru matematika memberikan kesan yang baik tidak menutup kemungkinan para murid mempunyai persepsi tentang guru tersebut.

Dalam bukunya yang berjudul Kepribadian Guru, (Zakiyah Darajat, 2005:67) mengambil pengertian bahwa "persepsi adalah pendapat, pikiran atau pandangan ketika melihat sesuatu yang dianggap sangat penting".

Bisa diambil kesimpulan bahwa persepsi adalah pandangan, pikiran dan pendapat yang logis sesuai dengan kenyataan yang ada terhadap suatu objek.

Menurut asal katanya, kepribadian atau personality berasal dari bahasa latin personare, yang berarti mnegeluarkan suara (to sound through). Kini istilah personality oleh para ahli psikologi dipakai untuk menunjukkan sesuatu yang nyata dan dapat dipercaya tentang individu, untuk menggambarkan bagaimana dan apa sebenarnya individu itu.

Ramayulis dalam judul bukunya (Ilmu Pendidikan Matematika, 1998:188), mengemukakan pengertian kepribadian secara umum yaitu "Keseluruhan tingkah laku yang tampak dalam ciri khas seseorang". Pengertian ini sejalan dengan analisis yang dikemukakan oleh Ahmad Fauzi dalam bukunya (Psikologi Umum, 1997:121) bahwa :

"Kepribadian adalah seluruh poola (bentuk) tingkah laku, sifat-sifat, kebiasaan, kecakapan, bentuk tubuh serta unsure-unsur psikologi fisik yang lainnya yang selalu menampakkan diri dalam kehidupan seseorang" (Ahmad Fauzi, Psikologi Umum, 1997:121)

Dari uraian diatas dapat disimpulkan bahwa kepribadian adalah keseluruhan tingkah laku seseorang (character dan behavior) yang tampak sebagai ciri khas, yang dapat dilihat dari sikap dan prilaku kehidupannya sehari-hari.

Oemar Hamalik menerangkan bahwa guru merupakan key person (orang utama) dalam kelas. Guru memimpin dan mengarahkan kegiatan belajar para siswanya, guru yang paling banyak berhubungan dengan para siswa dibandingkan dengan personal lainnya (Oemar Hamalik, Psikologi Belajar Mengajar, 1992:27)

A.Sadli memaparkan pengertian guru adalah sebagai berikut :

"Individu yang akan memenuhi kebutuhan anak didik dalam bidang pengetahuan, melalui proses interaksi dalam rangka penyampaian dan penerimaan pendidikan, baik yang bersifat kognitif maupun psikomotor" (A.Sadli, 2005:56) 
Dari uraian diatas dapat disimpulkan bahwa guru adalah seorang pendidik atau pembimbing yang tugasnya untuk mendidik dan mengarahkan kegiatan belajar siswa maupun sebagai pengajar dalam proses mengajar.

Kualifikasi kepribadian guru dipandang sangat penting oleh sebab itu tugas guru (pendidik) bukan saja melaksanakan pendidikan, ia juga dituntut dapat memperbaiki pendidikan yang telah terlanjur salah diterima anak sekaligus mengadakan pendidikan ulang. Tingkah laku atau moral guru pada umumnya, merupakan penampilan lain dari kepribadiannya. Bagi anak didik yang masih kecil, guru adalah contoh teladan yang sangat penting dalam pertumbuhannya, guru adalah orang pertama sesudah orang tua yang mempengaruhi pembinaan kepribadian anak didik. Mengingat begitu urgennya kepribadian guru, maka Al-Ghazali mengemukakan kepribadian seorang pendidik atau guru sebagai berikut :

a. Sabar menerima masalah yang ditanyakan murid dan harus diterima baik

b. Senantiasa bersifat kasih dan tidak pilih kasih

c. Jika duduk harus sopan dan tunduk (tidak ria)

d. Bersikap Tawadhu

e. Sikap dan pembicarannya tidak main-main

f. Menanamkann sikap bersahabat didalam artinya terhadap semua muridnya

g. Menyantuni serta tidak membentak orang yang bodoh

h. Membimbing dan mendidik murid

i. Berani berkata "saya tidak tahu" terhadap masalah yang tidak dimengerti

j. Menampilkan hujjah yang benar, apabila ia berada dalam hal yang salah bersedia rujuk pada kebenaran.

Dari uraian diatas, maka dapat ditarik kesimpulan bahwa kepribadian guru matematika adalah keseluruhan tingkah laku seorang pendidik atau guru untuk memikat perhatian anak didiknya melalui sifat-sifat yang semestinya ada dan intern dalam diri guru matematika yang bersangkutan, yang sering kali tercermin dalam sikap cara berbicara, bertindak, berprilaku keadaan emosi serta penampilan yang diperlihatkan selama berlangsung proses belajar mengajar maupun diluar proses belajar mengajar. Seorang guru matematika hendaknya memiliki karakteristik kepribadian yang ideal, diantaranya yaitu memiliki sifat-sifat yang terpuji.

Maka bisa diambil kesimpulan bahwa persepsi siswa terhadap kepribadian guru adalah pendapat seorang siswa terhadap gurunya mulai dari kepribadian seorang guru yang bertingkah laku, berwibawa, jujur, bertanggung jawab, pemaaf, disiplin, dan loyalitas terhadap bangsa dan negaranya.

\section{Jenis Kelamin}

Masalah jenis kelamin sebenarnya masalah kodrat, pembahasan tentang jenis kelamin pria dan wanita telah banyak dilakukan oleh para ahli dari berbagai bidang ilmu, pembahasan tersebut sampai sekarang berjalan terus. Menurut Kartini Kartono yang dikutip dari skripsi Dodih Damhudi pada hakekatnya wanita lebih bersifat heterosentris dan sosial apabila dibandingkan oleh pria sehingga pekerjaan yang bersifat social seperti guru, juru rawat dan pekerjaan social lainnya lebih menarik bagi wanita, sedangkan pris lebih bersifat egosentris sehingga pria lebih tertarik kepada pekerjaan yang membutuhkan pikiran yang bersifat objektif.

Sedangkan menurut Ngalim Purwanto dalam Ki Hajar Dewantara (1990:6) juga berpendapat bahwa "tubuh wanita berbeda dengan pria, kodrat wanita yaitu: kewajibannya akan menjadi ibu, mengandung anak, melahirkan anak dan lain-lain. Tabiat perempuan dan laki-laki berbeda, karena ada perbedaan antara hal-hal lahir (pakaian, 
tingkah laku, perbuatan, pekerjaan) dan hal lain (rasa, adab, cinta kasih, malu, kehalusan budi, kesucian, etika dan lain-lain)

Kadar daya serap anak didik terhadap bahan pelajaran bervariasi dengan tingkat keberhasilan mulai dari kurang, minimal, optimal, dan maksimal. Adanya perbedaan jenis kelamin juga merupakan salah satu factor yang menyebabkan kadar daya serap anak didik terhadap bahan pelajaran bervariasi. Anak laki-laki (sebagai suatu kelompok) memperlihatkan variabilitas yang lebih besar daripada anak perempuan dalam penyebaran intelegensi. Artinya lebih banyak anak laki-laki yang lemah dalam intelegensi dibandingkan dengan anak perempuan, namun banyak anak laki-laki yang menunjukkan superioritas dalam intelegensi dibandingkan anak perempuan. Rata-rata siswa laki-laki melebihi siswa perempuan dalam hal berfikir umum (general reasoning), dan aspek-aspek tertentu tentang informasi umum. Laki-laki cenderung melebihi perempuan dalam kecepatan dan koordinasi gerakan-gerakan badan yang besar, pengamatan ruang, dan bakat mekanis. Adapun anak perempuan cenderung lebih unggul dalam ingatan, penggunaan bahasa, perhitungan angka dan kecepatan perceptual.

\section{METODE}

\section{Tujuan Penelitian}

Tujuan penelitian ini adalah untuk :

1. Mengetahui dan menganalisis hubungan antara persepsi siswa terhadap kepribadian guru dan jenis kelamin dengan minat belajar matematika di SMA Yaspen Tugu Ibu Depok.

2. Mengetahui dan menganalisis hubungan antara jenis kelamin siswa dengan minat belajar matematika

3. Mengetahui dan menganalisis hubungan antara persepsi siswa terhadap kepribadian guru dan jenis kelamin siswa dengan minat belajar matematika di SMA Yaspen Tugu Ibu Depok.

\section{Tempat dan Waktu Penelitian}

Penelitian ini dilaksanakan di SMA Tugu Ibu Depok yang beralamat di Jl. Sentosa Raya No. 2 Depok II Tengah. Sekolah ini merupakan sekolah yang sudah 3 tahun dilatih untuk menjadi sekolah berstandar nasional. Penelitian dilakukan pada siswa kelas XI pada tahun ajaran 2009-2010 yang berlangsung selama 5 bulan yang dimulai pada bulan April 2009 dan berakhir pada bulan Agustus tahun 2009. 


\section{Metode Penelitian}

Penelitian dengan menggunakan metode deskriptif korelatif. Dengan desain penelitian sebagai berikut :

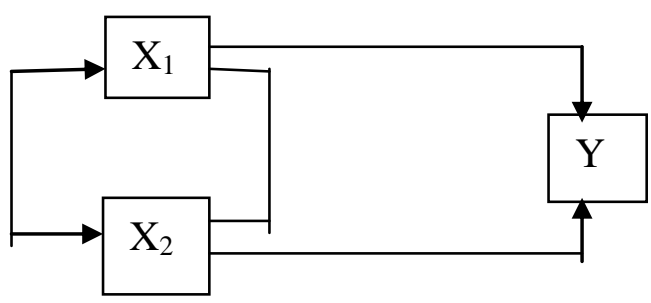

Keterangan:

$$
\begin{array}{ll}
\mathrm{X}_{1} & : \text { Kepribadian guru matematika } \\
\mathrm{X}_{2} & : \text { Jenis Kelamin } \\
\mathrm{Y} & : \text { Minat Belajar Matematika }
\end{array}
$$

\section{Populasi dan sampel Penelitian}

Populasi target dalam penelitian ini adalah seluruh siswa kelas XI SMA Tugu Ibu Depok. Sedangkan populasi terjangkaunya adalah seluruh siswa SMK kelas XI SMA Tugu Ibu Depok yang terdaftar pada tahun pelajaran 2009/2010.

Sampel dalam penelitian ini adalah siswa SMA kelas XI di Depok yang terdaftar pada tahun pelajaran 2009/2010. Diambil dari populasi terjangkau secara acak sebanyak 30 siswa.

Dari populasi terjangkau yaitu 120 siswa ditetapkan untuk mengambil sebanyak 30 orang sebagai sampel atau sama dengan 25\%. Pengambilan sampel dilakukan dengan random sampling, hingga siswa dalam tiap kelas berkesempatan untuk menjadi sampel. Hal ini sesuai dengan pendapat Dr. Suharsimi Arikunto yang berbunyi "Untuk populasi kurang dari 100 responden, dapat diambil 50\%, sedangkan untuk populasi lebih dari 100 responden, diambil 10\% sampai 25\%. (Dr. Suharsimi Arikunto, Prosedur Penelitian, 1993:140).

\section{HASIL DAN PEMBAHASAN}

Statistik Deskriptif

\begin{tabular}{|c|c|c|}
\hline Sumber Varians & $\begin{array}{c}\text { KGM } \\
\left(\mathrm{X}_{1}\right)\end{array}$ & MBM (Y) \\
\hline Mean & 44,33 & 44,85 \\
\hline Median & 44,26 & 44,66 \\
\hline Modus & 95,87 & 44,6 \\
\hline Standar Deviasi & 3,65 & 3,19 \\
\hline
\end{tabular}

\section{Pengujian Persyaratan Analisis}

Kriteria uji normalitas dengan Chi Kuadrat :

Jika $X_{\text {hitung }}^{2} \geq X_{\text {tabel, }}^{2}$ maka distribusi data tidak normal

Jika $X_{\text {hitung }}^{2} \leq X_{\text {tabel, }}^{2}$ maka distribusi data normal

\section{Kriteria uji linearitas}

Jika $\mathrm{F}_{\text {linier (hitung) }} \leq \mathrm{F}_{\text {linier (tabel), }}$, maka terima $\mathrm{H}_{\mathrm{O}}$ berarti LINIER

Jika $F_{\text {linier (hitung) }} \geq \mathrm{F}_{\text {linier (tabel) }}$, maka terima $\mathrm{H}_{\mathrm{a}}$ berarti TIDAK LINIER 
Tabel rangkuman uji persyaratan analisis data :

\begin{tabular}{|l|l|l|}
\hline \multicolumn{1}{|c|}{ Variabel } & \multicolumn{1}{|c|}{ Uji Normalitas } & \multicolumn{1}{c|}{ Uji Linearitas } \\
\hline Kepribadian Guru & $\mathrm{X}_{\text {hitung }}^{2} \leq \mathrm{X}_{\text {tabel, }}$ atau $7,31 \leq 7,815$ & $\mathrm{~F}_{\text {linier (hitung) }} \leq \mathrm{F}_{\text {linier (tabel) }}$, atau \\
Matematika & Kesimpulan: Data $\mathrm{X}_{1}$ berdistribusi \\
Normal & $\begin{array}{l}\text { disimpulkan bahwa metode } \\
\text { regresi Y atas } \mathrm{X}_{1} \text { berpola } \\
\text { LINIER }\end{array}$ \\
\hline $\begin{array}{l}\text { Minat Belajar } \\
\text { Matematika }\end{array}$ & $\begin{array}{l}\mathrm{X}_{\text {hitung }}^{2} \leq \mathrm{X}_{\text {tabel, }}^{2} \text { atau 3,08 } \leq 9,488 \\
\text { Kesimpulan: Data } \mathrm{X}_{2} \text { berdistribusi } \\
\text { Normal }\end{array}$ & \\
\hline
\end{tabular}

\section{Uji Hipotesis}

Dari perolehan nilai koefisien korelasi berganda diatas. Bahwa korelasi antara variable kepribadian guru matematika $\left(\mathrm{X}_{1}\right)$ dan jenis kelamin siswa $\left(\mathrm{X}_{2}\right)$ terhadap minat belajar matematika pada SMA Yaspen Tugu Ibu Depok, memiliki korelasi yang tergolong kuat dan positif sebesar $\mathbf{0 , 6 5}$.

Koefisien Determinasi $(\mathrm{KD})=\mathbf{4 2 , 2 5} \%$

Keberartian korelasi ganda $(\mathrm{R})$ dengan uji $\mathrm{F}$ sebesar $=\mathbf{1 0 , 5 6}$

Kaidah uji signifikansi: jika $F_{\text {hitung }} \geq F_{\text {tabel }}$, maka nilai $F_{\text {tabel }}$ dengan $\propto=0.05$ untuk uji dua pihak didapatkan bahwa $F_{\text {hitung }} \geq \mathrm{F}_{\text {tabel }}$ atau 10,56 $\geq \mathbf{3 , 2 5}$ (maka terdapat hubungan yang signifikan antara persepsi siswa terhadap kepribadian guru dan jenis kelamin dengan minat belajar matematika)

\section{Pembahasan}

Berdasarkan teori maupun hasil pengolahan, analisis dan hasil penafsiran data statistik mengenai analisa deskripsi data kepribadian guru matematika dan jenis kelamin terhadap minat belajar matematika, didapat interpretasi hasil penelitian sebagai berikut :

1. Analisis deskripsi data persepsi siswa terhadap kepribadian guru matematika memberikan pengaruh yang berarti terhadap minat belajar matematika.

2. Analisis deskripsi data persepsi siswa terhadap kepribadian guru matematika samasama berdistribusi normal.

3. Analisis deskripsi data persepsi siswa terhadap kepribadian guru matematika memiliki pengaruh yang sangat signifikan.

4. Analisis deskripsi data persepsi siswa terhadap kepribadian guru matematika berpola linier.

5. Analisis deskripsi data jenis kelamin siswa terhadap minat belajar matematika berpengaruh negatif.

6. Analisis data persepsi siswa terhadap kepribadian guru dan jenis kelamin siswa berpengaruh positif terhadap minat belajar matematika.

7. Analisis data persepsi siswa terhadap kepribadian guru dan jenis kelamin siswa terhadap minat belajar matematika memiliki hubungan yang signifikan yaitu $F_{\text {hitung }} \geq$ $\mathrm{F}_{\text {tabel }}$ atau $\mathbf{1 0 , 5 6} \geq \mathbf{3 , 2 5}$

8. Analisis data persepsi siswa terhadap kepribadian guru dan jenis kelamin siswa memiliki korelasi yang tergolong kuat sebesar $\mathbf{0 , 6 5}$.

\section{KESIMPULAN}

1. Terdapat hubungan yang positif dan signifikan antara persepi siswa terhadap kepribadian guru dengan minat belajar matematika, dengan diperoleh $\mathrm{r} x_{1} Y$ sebesar 
0,41 dengan demikian semakin tinggi persepsi siswa terhadap kepribadian guru maka akan semakin tinggi minat belajar matematika siswa.

2. Terdapat hubungan yang negatif dan signifikan antara jenis kelamin siswa dengan minat belajar matematika, diperoleh $\mathrm{r} x_{2} Y$ sebesar $-0,40$ hal ini menunjukkan bahwa jenis kelamin siswa laki-laki minat belajar matematikanya lebih tinggi daripada siswa perempuan.

3. Terdapat hubungan yang positif dan signifikan antara persepsi siswa terhadap kepribadian guru dan jenis kelamin siswa dengan minat belajar matematika dengan diperoleh $r x_{1} x_{2} y$ sebesar 0,65 .

\section{IMPLIKASI}

Implikasi hasil penelitian ini adalah pentingnya kepribadian guru terhadap minat belajar siswa. Perlu pula diperhatikan bahwa dalam membantu pelajaran matematika tidak selamanya berfungsi pada persepsi kepribadian guru matematika dan jenis kelamin terhadap minat belajar matematika.

Implikasi lainnya adalah guru dituntut untuk melaksanakan metode pengajaran dan kepribadian yang baik sesuai dengan minat belajar siswa/i SMA Tugu Ibu Depok dalam hubungannya dengan belajar matematika tahun pelajaran 2009/2010.

\section{SARAN}

Berdasarkan kesimpulan dan implikasi di atas, dapat disampaikan saran sebagai berikut. (1) Untuk setiap guru matematika, hendaknya lebih mampu meningkatkan kepribadian dirinya dalam berinteraksi dengan siswa, baik laki-laki maupun perempuan khususnya pada setiap kegiatan proses belajar mengajar berlangsung. Dengan melihat penilaian siswa di atas, setidaknya dapat kita ketahui bahwa aspek mana dari kepribadian diri kita sebagai seorang pendidik yang perlu diperbaiki dan ditingkatkan sehingga kita dapat mampu melaksanakan kurikulum dengan baik secara berhasil. (2) Untuk pihak sekolah, dalam penerimaan calon tenaga kependidikan hendaknya lebih memperhatikan standar kualifikasi guru yang baik/ideal, yaitu figure guru yang memiliki kompetensi dan kepribadian yang baik. Karena dengan terpenuhinya persyaratan tersebut akan dapat menunjang keberhasilan proses pembelajaran di sekolah tersebut, sehingga tercapai hasil pembelajaran yang optimal. (3) Untuk para siswa/i, hendaknya minat belajar matematika yang ada pada saat ini lebih ditingkatkan lagi. Terutama dengan menerapkan kesadaran, keimanan, harapan dan cita-cita pada diri masing-masing untuk meraih sebanyak dan setinggi mungkin Ilmu Pengetahuan. (4) Untuk semua pihak, terutama orang tua siswa/i dan masyarakat sekitarnya, hendaklah terlibat aktif membimbing dan mengarahkan anakanaknya.

\section{DAFTAR PUSTAKA}

Abdurahman, Muryono, 2003. Pendidikan Bagi Anak Berkesulitan Belajar. Jakarta: Rineka Cipta.

Abrar, Abd Rahman, 1995. Behavioral Performance. Bandung: Remaja Rosdakarya. Arikunto.Suharsimi, 1990. Prosedur Penelitian Suatu Pendekatan Praktek. Jakarta: Rineka Cipta.

Arikunto, Suharsimi, 2005. Evaluasi Proses Belajar Mengajar. Jakarta: Rineka Cipta.

Darajat, Zakiah, 1980. Kepribadian Guru. Jakarta: Bulan Bintang.

Depdikbud, 1993. Kamus Besar Bahasa Indonesia. Jakarta: Balai Pustaka.

Depdikbud, 1998. Petunjuk Teknis Mata Pelajaran Matematika. Jakarta.

Fauzi, Ahmad. Psikologi Umum. Bandung: Pustaka Setia. 
Hamalik, Oemar, 1990. Perencanaan Pengajaran Berdasarkan Pendekatan Sistem. Bandung: Citra Aditya.

Hamalik, Oemar, 1992. Psikologi Belajar Mengajar Perencanaan. Bandung: Sinar Baru Algensind.

Marimba, A.D. 1996. Pengantar Filsafat Pendidikan, Bandung.

Jalaluddin, Dr dan Ramayulis, 1993. Pengantar Ilmu Jiwa Agama. Jakarta: Izlam Mulia.

Purwanto, M.Ngalim, 1990. Psikologi Pendidikan, Bandung: Remaja Rosda Karya.

Sudjana, Nana, 1999. Bentuk-bentuk Tes Formatif. Jakarta: Departeman Pendidikan Nasional.

Sumartana, 1999. Tes Kesiapan Belajar. Bandung : Remaja Rosda Karya.

Slameto, 2003. Belajar dan Faktor-Faktor yang Mempengaruhinya. Jakarta:Rineka Cipta.

Shalahudin, Mahfudh, 1990. Pengantar Psikologi Pendidikan, Surabaya: Bina Ilmu.

Sukino. Wilson Simangunsong, 2006. Matematika Untuk SMP Kelas VIII. Erlangga: Jakarta. 